\title{
Faktor Internal dan Eksternal Penentu Kesejahteraan Petani Jambu Mete di Desa Mata Kapore Kabupaten Sumba Barat Daya
}

\author{
Internal and External Factors Determining Welfare of Jambu Mete Farmers \\ in Mata Kapore Village, Sumba Barat Daya District \\ Yustina Sriyutun Saghu, Agnes Quartina Pudjiastuti, Sumarno \\ Program Studi Ekonomi Pertanian, Sekolah Pascasarjana \\ Universitas Tribhuwana Tungga Dewi, Malang \\ ${ }^{*}$ Kontak Penulis: agnespudjiastuti@yahoo.com
}

\begin{abstract}
Indonesia's cashew export potential is quite large, but its value is still very low. The purpose of this study was to analyze the influence of internal and external factors on the welfare of cashew farmers. This research was conducted at the cashew production center, namely Mata Kapore Village, which is located in Kodi Bangedo District, Southwest Sumba Regency. Data was collected from 50 farmers using interview and observation methods. Farmers were selected by a simple random method. Data analysis used structural equation modeling (SEM) based on variance, namely Partial Least Square (PLS). External factors have a very significant effect on the welfare of farmers, either directly or indirectly through internal factors. Internal factors have no significant effect on farmers' welfare. To improve farmers' welfare, it is necessary to support access to capital and price guarantees for cashew farmers.
\end{abstract}

Keywords: farmer's welfare; cashew; internal factor; external factors.

Abstrak

Potensi ekspor mete Indonesia cukup besar, namun nilainya masih sangat rendah. Tujuan penelitian ini adalah menganalisis pengaruh faktor internal dan eksternal pada kesejahteraan petani mete. Penelitian ini dilaksanakan di sentra produksi jambu mete yaitu Desa Mata Kapore yang terletak di Kecamatan Kodi Bangedo Kabupaten Sumba Barat Daya. Data dikumpulkan dari 50 petani dengan menggunakan metode wawancara, dan observasi. Petani dipilih dengan metode acak sederhana. Analisis data menggunakan structural equation modeling (SEM) berbasis varians yaitu Partial Least Square (PLS). Faktor eksternal berpengaruh sangat signifikan terhadap kesejahteraan petani, baik secara langsung maupun secara tidak langsung melalui faktor internal. Faktor internal tidak berpengaruh signifikan pada kesejahteraan petani. Untuk meningkatkan kesejahteraan petani, perlu adanya dukungan akses pada modal dan jaminan harga bagi petani jambu mete.

Kata kunci: kesejahteraan petani; mete; faktor internal; faktor eksternal.

\section{Pendahuluan}

Mete merupakan salah satu komoditas yang menjadikan Indonesia sebagai negara eksportir karena memiliki indeks spesialisasi perdagangan yang positif (Zahir \& Sanawiri, 2018). Ekspor komoditas ini akan berkontribusi positif terhadap neraca perdagangan (Pudjiastuti et al., 2013; Pudjiastuti, 2014; Pudjiastuti \& Kembauw, 2018). Kacang mete di Indonesia tergolong sebagai industri sedang tumbuh dan berorientasi ekspor (Indrawanto, 2004), tetapi belum memiliki keunggulan komparatif berdasarkan RCA indeks (Fauziyah et al., 2017). Namun Guledgudda et al. (2014) menyebutkan bahwa di pasar dunia, Indonesia dianggap major competitor bagi India, selain Vietnam, 
Brazil dan Tanzania. Secara ekonomi, jambu mete menghasilkan devisa negara, bahan baku industri, tanaman penghijauan dan sumber pendapatan petani (Kurniawan, 2016). Ditjenbun (2019) menyebutkan bahwa jambu mete dibudidayakan dan tersebar di seluruh wilayah Pulau Sulawesi, Nusa Tenggara dan sebagian besar Pulau Jawa. Pada tahun 2018, terdapat 6 (enam) provinsi yang mempunyai populasi tanaman jambu mete terluas di Indonesia. Berturut-turut dari yang terluas yaitu Provinsi Nusa Tenggara Timur dengan luas 171.086 hektar, Sulawesi Tenggara seluas 116.061 hektar, Nusa Tenggara Barat seluas 44.947 hektar, kemudian Provinsi Sulawesi Selatan, Jawa Timur dan Jawa Tengah.

Di beberapa daerah penghasil jambu mete, pengembangan komoditas ini masih dihadapkan pada berbagai kendala, yaitu: 1) bahan tanaman, 2) lingkungan tumbuh, 3) hama-penyakit, dan 4) manajemen kebun. Apabila kendala tersebut dapat diatasi, maka produktivitas mete dapat ditingkatkan. Namun, pengalaman empiris menunjukkan hal tersebut sering terabaikan (Hakim, 2018). Dalam pengembangannya, industri jambu mete nasional menghadapi berbagai permasalahan antara lain areal kebun jambu mete per petani sempit dan tanaman jambu mete pada umumnya sudah tua dengan produktivitas yang rendah karena pengelolaan pascapanen yang masih dilakukan belum menggunakan inovasi modern. Salah satu upaya untuk meningkatkan produktivitas yang berdampak pada peningkatan pendapatan petani jambu mete adalah dengan pengelolaan input usaha tani (Ditjenbun; 2019).

Produksi jambu mete di Nusa Tenggara Timur tahun 2018-2020 secara berturutturut tercatat sebesar 147,60 ribu ton, 162,40 ribu ton, dan 157,40 ribu ton. Angka ini lebih tinggi dibandingkan tahun 2015-2017 masing-masing 137,50 ribu ton, 137 ribu ton, dan 135,50 ribu ton (BPS, 2021). Meningkatnya produksi jambu mete ini bersumber pada bertambahnya luas panen, karena produktivitasnya ternyata terus menurun dari $572 \mathrm{~kg} /$ ha pada tahun 2018 menjadi $557 \mathrm{~kg} /$ ha pada tahun 2020.

Jambu mete mempunyai peran penting sebagai sumber mata pencaharian sebagian besar penduduk di Kabupaten Sumba Barat Daya. Usaha tanaman ini telah dilaksanakan sejak lama, sehingga kesejahteraan masyarakat petani tergantung pada produksi mete yang dihasilkan, termasuk di Desa Mata Kapore.

Desa Mata Kapore yang terletak di Kecamatan Kodi Bangedo termasuk sentra produksi mete, dimana petani telah tergabung dalam kelompok tani. Namun, lembaga ini hanya berfungsi sebagai tempat memperoleh informasi dan administrasi saja. Usahatani jambu mete juga dilaksanakan dengan permodalan yang lemah. Hal ini disebabkan oleh kurangnya kemampuan keuangan internal petani, sementara akses modal ke pihak eksternal (bank) baru mulai diperkenalkan. Petani lebih banyak meminjam uang kepada pedagang pengumpul yang telah menjalin kerjasama sejak lama dan menjamin pemasaran hasil panen. Harga mete sebesar Rp. 22.500 -- Rp. 25.000 per $\mathrm{kg}$, akan menghasilkan penerimaan yang rendah jika produksinya rendah. Situasi ini seperti yang dinyatakan oleh Iqbal \& Dalimi (2006) bahwa permasalahan petani tidak hanya di aspek produksi dan pasca panen, tetapi juga masalah kelembagaan. Namun, Yusria (2010) dan Fyka et al. (2019) menemukan bahwa rumah tangga petani jambu mete di Kabupaten Buton Sulawesi Selatan tergolong sejahtera, diukur dari pendapatan yang diperoleh.

Oleh karena penerimaan usahatani jambu mete dipengaruhi oleh faktor internal dan eksternal, maka kesejahteraan petani juga tergantung pada kedua faktor tersebut. Sutaminingsih \& Sujana (2020) dan Hartarti et al. (2017) menyebutkan bahwa faktor 
internal terdiri dari tenaga kerja keluarga dan luas lahan, sementara faktor eksternal meliputi ketersediaan faktor produksi, harga faktor produksi, permintaan produksi dan harga jual.

Tujuan penelitian ini adalah menganalisis pengaruh faktor internal dan eksternal pada kesejahteraan petani jambu mete di Kecamatan Kodi Bangedo Kabupaten Sumba Barat Daya.

\section{Metode Penelitian}

Penelitian ini dilaksanakan di Desa Mata Kapore karena merupakan sentra jambu mete di Kecamatan Kodi Bangedo Kabupaten Sumba Barat Daya. Data primer dikumpulkan dari 50 petani yang dipilih secara acak sederhana dengan pertimbangan bahwa luas penguasaan lahan yang homogen. Pengumpulan data menggunakan metode wawancara dengan kuesioner sebagai instrumen penelitian dan dilengkapi dengan observasi ke lahan dan rumah tinggal petani. Data sekunder diperoleh dari dokumen Badan Pusat Statistik (BPS), Kementerian Perdagangan dan Industri, serta kajian empiris sebelumnya yang telah dipublikasikan.

Data yang telah dikumpulkan, diedit di lapang dan ditabulasi, yang selanjutnya dianalis dengan structural equation modeling (SEM) dengan Partial Least Square (PLS). PLS merupakan jenis analisis SEM yang berbasis komponen dengan sifat konstruk formatif. PLS pertama kali digunakan untuk mengolah data di bidang economertrics sebagai alternative teknik SEM dengan dasar teori yang lemah.

Ada 3 (tiga) variabel laten yang digunakan yaitu faktor internal, faktor eksternal dan kesejahteraan petani jambu mete. Faktor internal meliputi usia, pendidikan, jumlah anggota keluarga, jumlah modal yang digunakan, luas lahan yang dimiliki, dan pengalaman berusahatani. Faktor eksternal terdiri dari: peran penyuluh, akses ke modal, jumlah modal yang dipinjam, jumlah produksi, harga mete. Peran penyuluh diukur dengan persepsi petani tentang kinerja penyuluh sebagai motivator dan fasilitator dengan 5 skala likert. Akses ke modal diukur dengan persepsi petani tentang perolehan modal dari lembaga keuangan. Kesejahteraan didekati dengan: pendapatan petani, kondisi tempat tinggal dan nilai tukar petani. Kondisi tempat tinggal diukur berdasarkan jenis bangunannya: atap (alang-alang atau seng), lantai (tanah, bambu, keramik) dan dinding (bambu, atau batu alam). Tahapan analisis meliputi analisis outer model dan inner model, serta pengujian hipotesis. Outer model digunakan untuk mengetahui validitas dan reliabilitas data. Validitas data didasarkan pada discriminant validity di mana kriteria nilai loading pada konstruk yang dituju harus lebih besar dibandingkan nilai loading konstruk yang lain. Uji reliabilitas didasarkan pada nilai cronbach alpha dengan kriteria $>0.6$ untuk semua konstruk.

Tahapan dalam model SEM PLS adalah:

a) Spesifikasi model dengan estimasi berulang (iterative) skor variabel laten yang terdiri dari 4 langkah berikut ini. Langkah 1: Aproksimasi outer model, yaitu perhitungan skor variabel laten, berdasarkan skor indikator dan koefisien outer (loading) dari langkah 4. Langkah 2: Estimasi proksi model struktural atau hubungan antar variabel laten (inner model). Langkah 3: Aproksimasi inner skor variabel laten berdasarkan skor variabel dari langkah 1 dan proksi model struktural dari langkah 2 . Langkah 4: Estimasi proksi untuk koefisien model pengukuran (hubungan antara indikator dan variabel laten dari langkah 3). 
b) Weight Relation: Estimasi final untuk koefisien (outer weight dan loadingnya serta model struktural) yang ditentukan dengan metode ordinary least squares (OLS) untuk setiap regresi parsial dalam model SEM-PLS.

\section{Hasil dan Pembahasan}

\section{Kesejahteraan Petani Jambu Mete di Desa Mata Kapore}

Desa Mata Kapore merupakan desa terluas di Kecamatan Kodi Bangedo. Luas wilayah desa ini mencapai 1183 hektar atau 16,16\% dari luas wilayah kecamatan. Curah hujan yang tinggi terjadi sekitar bulan Desember hingga Maret dengan jumlah hari hujan bervariasi di sepanjang tahun. Suhu berkisar 22 - 29o, kelembaban 72-87\%, $84 \%$ tekstur tanahnya tergolong sedang, menjadikan wilayah ini sesuai untuk budidaya komoditas pertanian. Desa ini termsuk ke dalam kategori swakarya. Kantor desa memiliki bangunan yang permanen. Jumlah penduduk tercatat 2.543 jiwa. Menurut gender, terdapat 1301 laki-laki dan 1242 perempuan, dengan rasio 105. Kepadatan penduduk di desa ini sebesar 215 jiwa per $\mathrm{km}$ persegi, paling rendah dibanding 14 desa lainnya. Secara keseluruhan, desa ini meningkat kesejahteraannya karena sejak tahun 2018, sudah tidak ada lagi warga yang menderita gizi buruk (pada tahun 2017 tercatat 36 warga). Untuk mengatasi kekurangan air pada musim kemarau, desa telah membuat embung sebanyak 2 unit pada tahun 2018, yang berkurang jumlahnya menjadi 1 unit pada tahun 2019. Infrastruktur jalan raya masih berupa batu/kerikil yang diperkeras, tetapi bisa dilalui kendaraan bermotor roda 4 atau lebih sepanjang tahun. Tidak ada menara telepon seluler di wilayah ini, namun ada 1 operator layanan komunikasi telepon ini yang dapat menjangkau seluruh desa dengan kondisi sinyal yang lemah. Tidak ada kantor pos/pos pembantu/rumah pos, demikian juga perusahaan jasa ekspedisi.

Petani jambu mete di desa penelitian memiliki karakteristik berdasarkan umur, pendidikan, jenis kelamin, jumlah tanggungan, pengalaman bertani yang disajikan di Tabel 1.

Tabel 1

Karakteristik Petani Jambu Mete di Desa Mata Kapore

\begin{tabular}{llcc}
\hline No & Karakteristik & Jumlah (orang) & Persentase (\%) \\
\hline 1 & Umur (tahun) & & \\
& 35-44 & 23 & 46 \\
& $45-54$ & 17 & 34 \\
& 55-64 & 10 & 20 \\
2 & Pendidikan & & \\
& SD & 26 & 52 \\
& SMP & 15 & 30 \\
& SMA & 9 & 18 \\
Jenis Kelamin & & \\
& Laki-laki & 35 & 70 \\
& Perempuan & 15 & 30 \\
Lama berusahatani (tahun) & & \\
& 1-3 & 2 & 4 \\
& 4-6 & 14 & 38 \\
& $7-9$ & 19 & 30 \\
& 10-12 & 15 &
\end{tabular}


Sebagian besar $(76 \%)$ petani menjadikan jambu mete sebagai komoditas utama sumber penghasilan. Sisanya menggantungkan mata pencaharian tidak hanya dari usahatani jambu mete atau memiliki pekerjaan lain di luar usahatani. Seluruh (100\%) petani berada pada usia produktif, sehingga berani menanggung risiko dan adaptif pada perubahan teknologi baru atau inovasi. Tidak ada petani jambu mete yang menempuh pendidikan tinggi, sebagian besar (82\%) berpendidikan SD dan SMP. Ini menunjukkan bahwa usahatani komoditas ini tidak mensyaratkan pendidikan yang tinggi. Kondisi ini dijumpai di berbagai komoditas pertanian di berbagai wilayah. Umumnya, pendidikan informal melalui penyuluhan mampu meningkatkan pengetahuan dan ketrampilan petani. Usahatani ini ditekuni tidak hanya oleh laki-laki, tetapi juga oleh perempuan meskipun persentasenya lebih sedikit (30\%). Oleh karena itu, program pengembangan komoditas ini sebaiknya melibatkan perempuan juga karena ikut berkontribusi dalam pendapatan rumah tangga. Para petani umumnya (96\%) telah berpengalaman lebih dari 3 tahun dalam usahatani jambu mete.

\section{Faktor Penentu Kesejahteraan Petani Jambu Mete}

Pengaruh faktor internal dan faktor eksternal pada kesejahteraan petani jambu mete di Desa Mata Kapore yang dianalisis dengan SEM. Variabel laten eksogen ada dua yaitu faktor internal dan faktor eksternal, sementara variabel laten endogen adalah kesejahteraan petani. Faktor internal (X1) memiliki indikator (variabel manifest): jumlah anggota keluarga (X11), dan pengalaman berusahatani (X12). Dua variabel ini terpilih sebagai variabel manifest karena memiliki outer loading $>0,6$, sedangkan usia, pendidikan, jumlah modal yang digunakan dan luas lahan memiliki outer loading < 0,6. Faktor eksternal (X2) memiliki indikator peran penyuluh (X21), akses modal (X22), jumlah modal yang dipinjam (X23), harga kacang mete (X24). Kesejahteraan petani (Y) memiliki indikator pendapatan petani (Y1), dan kondisi rumah tinggal (Y2). Tahapan analisis meliputi evaluasi model pengukuran, evaluasi model struktural dan pengujian hipotesis diuraikan berikut ini.

1) Evaluasi Model Pengukuran (Outer Model)

Evaluasi atas model pengukuran mencakup tiga tahapan yaitu uji validitas konvergen, uji validitas diskriminan dan uji reliabilitas komposit.

- Uji Validitas Konvergen

Validitas indikator reflektif dapat diuji dengan menggunakan korelasi antara skor indikator dengan skor konstruknya. Pengukuran ini menunjukkan adanya perubahan suatu indikator dalam suatu konstruk apabila indikator lain pada konstruk yang sama berubah. Hasil perhitungan ini disajikan di Tabel 2 dan output pemodelan di Gambar 1 .

Menurut Ghozali (2012), suatu korelasi dikatakan memenuhi validitas konvergen apabila memiliki nilai loading $>0,5$. Output menunjukkan bahwa loading factor $>0,5$, sehingga indikator-indikator penelitian ini telah memenuhi validitas konvergen (convergent validity). 
Tabel 2

Outer Loading

\begin{tabular}{lccc}
\hline Indikator & $\begin{array}{c}\text { Faktor } \\
\text { Eksternal }\end{array}$ & $\begin{array}{c}\text { Faktor } \\
\text { Internal }\end{array}$ & Kesejahteraan \\
\hline Jumlah angota keluarga & & 0,670 & \\
Pengalaman kerja petani & & 0,670 & \\
Peran Penyuluh pertanian & 0,893 & & \\
Akses Modal & 0,769 & & \\
Jumlah Modal yang dipinjam & 0,792 & & 0,640 \\
Harga komoditi kacang mete & 0,803 & & 0,767 \\
Pendapatan petani mete (per tahun) & & & \\
Kondisi tempat tinggal & & & \\
Nilai Tukar Petani & & & \\
\hline
\end{tabular}

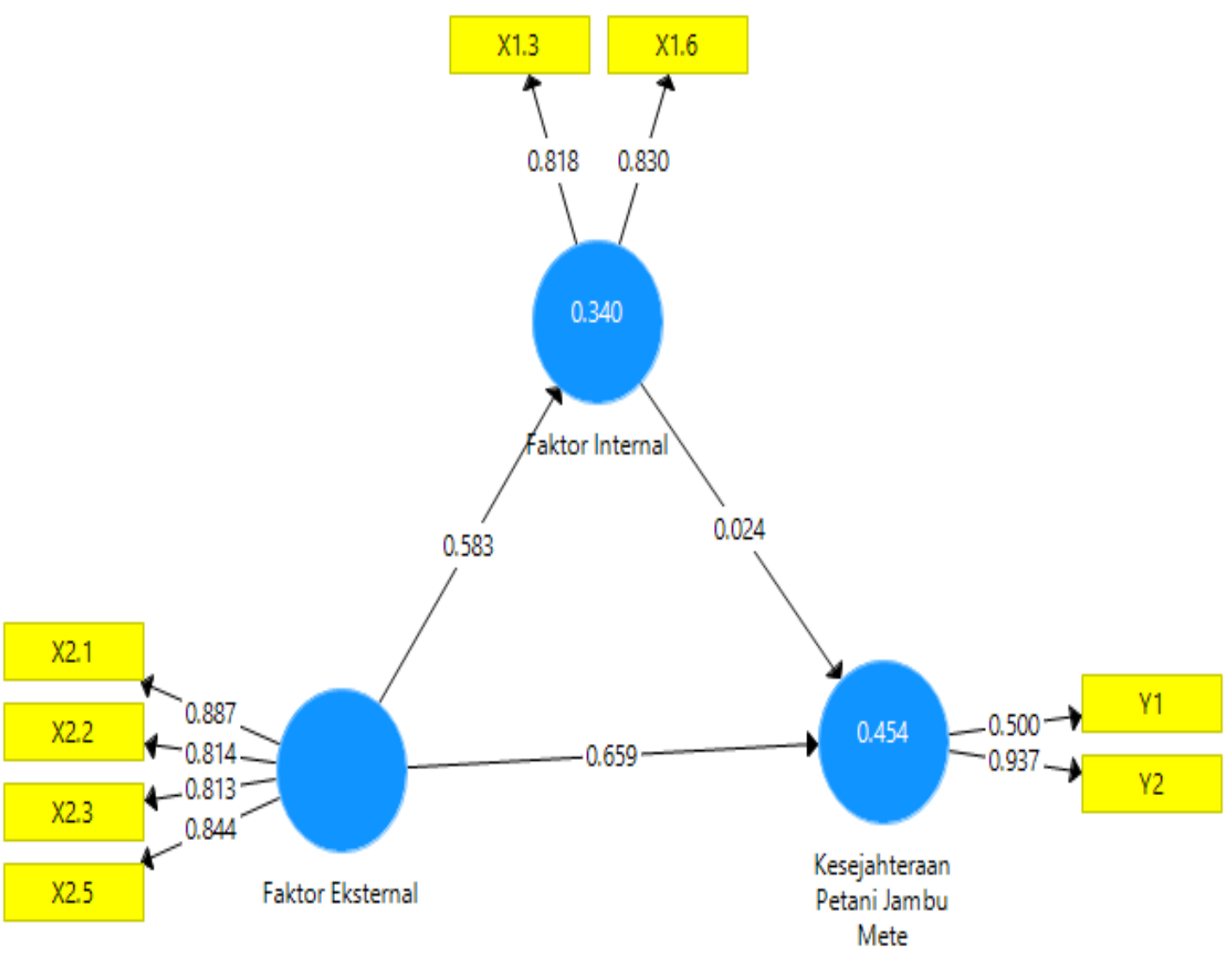

Gambar 1. Output Loading Factor Pemodelan

\section{- Uji Validitas Diskriminan}

Indikator reflektif perlu diuji validitas diskriminan (discriminant validity) dengan membandingkan nilai pada tabel cross loading. Indikator dinyatakan valid jika mempunyai nilai loading factor tertinggi ke konstruk yang dituju dibandingkan nilai loading factor ke konstruk lain. Cross loading indikator-indikator dari setiap variabel laten disajikan di Tabel 3 
Tabel 3

Output Cross Loading

\begin{tabular}{lcccc}
\hline \multirow{1}{*}{$\begin{array}{l}\text { Indikator } \\
\text { Jumlah angota keluarga }\end{array}$} & $\mathrm{X}_{11}$ & $\begin{array}{c}\text { Faktor } \\
\text { Internal }\end{array}$ & $\begin{array}{c}\text { Faktor } \\
\text { Eksternal }\end{array}$ & $\begin{array}{c}\text { Kesejahteraan } \\
\text { Petani }\end{array}$ \\
\cline { 2 - 5 } & $\mathrm{X}_{12}$ & 0,470 & $\mathrm{X}_{2}$ & $\mathrm{Y}$ \\
\hline Pengalaman berusahatani & $\mathrm{X}_{21}$ & 0,693 & 0,670 & 0,352 \\
Peran penyuluh pertanian & $\mathrm{X}_{22}$ & 0,769 & 0,433 & 0,404 \\
Akses modal & $\mathrm{X}_{23}$ & 0,792 & 0,549 & 0,696 \\
Jumlah modal yang dipinjam & $\mathrm{X}_{24}$ & 0,803 & 0,475 & 0,531 \\
Harga komoditi kacang mete & $\mathrm{Y}_{1}$ & 0,458 & 0,394 & 0,566 \\
Pendapatan petani mete & $\mathrm{Y}_{2}$ & 0,654 & 0,490 & 0,640 \\
Kondisi tempat tinggal & & & & 0,767 \\
\hline
\end{tabular}

- Uji Reliabilitas

Sarwono dan Narimawati (2015) menyatakan bahwa suatu variabel laten dapat dikatakan mempunyai validitas dan realibilitas yang baik apabila nilai AVE lebih besar dari 0,5 dan nilai composite reliability lebih besar dari 0,7.

Tabel 4

Hasil Uji Reliabilitas Variabel Laten

\begin{tabular}{lccc}
\hline \multicolumn{1}{c}{ Konstruk } & $\begin{array}{c}\text { Average } \\
\text { Extracted (AVE) }\end{array}$ & $\begin{array}{c}\text { Composite } \\
\text { Reliability }\end{array}$ & Keterangan \\
\hline Faktor Internal & 0,706 & 0,906 & valid dan reliabel \\
Faktor Eksternal & 0,679 & 0,809 & valid dan reliabel \\
Kesejahteraan petani & 0,564 & 0,703 & valid dan reliabel \\
\hline
\end{tabular}

Tabel 4 menunjukkan bahwa seluruh variabel-variabel laten yang diukur dalam penelitian ini memiliki nilai composite reliability yang lebih besar dibandingkan dengan 0,7 sehingga dapat dikatakan bahwa semua variabel laten reliabel. Selain itu, validitasnya tinggi karena Average Variance Extracted (AVE) >0,50.

2) Evaluasi Model Struktural (Inner Model)

Evaluasi model struktural pada SEM dengan PLS dilakukan dengan melihat nilai R-squared (R2) dan uji signifikansi melalui estimasi koefisien jalur untuk menguji hipotesis. Hipotesis yang diajukan adalah faktor eksternal berpengaruh signifikan baik langsung maupun tidak langsung pada kesejahteraan petani, faktor internal berpengaruh signifikan baik langsung maupun tidak langsung pada kesejahteraan petani.

- Goodness of fit Model

Nilai koefisien determinasi (R2) dipergunakan untuk mengukur seberapa besar kontribusi variabel laten independen tertentu terhadap variabel laten dependen. Berdasarkan hasil pengolahan data diperoleh koefisien determinasi faktor internal adalah 0,340 dan faktor eksternal adalah 0,454. Ini artinya, faktor internal berkontribusi 
pada variasi kesejahteraan petani sebesar 34\% dan faktor eksternal menjelaskan sebesar $45,4 \%$. Sisanya $(21,6 \%)$ dijelaskan oleh variabel lainnya di luar model ini. Dengan demikian, model yang dirancang dalam penelitian ini termasuk dalam kategori baik karena R2 0,795 > 0,67 seperti yang dikemukakan oleh Gozhali (2012).

- Uji Signifikansi

Uji signifikansi pada model SEM dengan PLS bertujuan untuk mengetahui pengaruh variabel eksogen terhadap variabel endogen. Pengujian hipotesis dengan metode SEM PLS dilakukan dengan cara melakukan proses bootstrapping sehingga diperoleh hubungan (pengaruh) variabel eksogen terhadap variabel endogen yang disajikan di Tabel 5.

Tabel 5

Hasil Perhitungan Bootstrapping (Inner Weights)

\begin{tabular}{|c|c|c|c|c|c|}
\hline Hubungan & $\begin{array}{c}\text { Original } \\
\text { Sample } \\
\text { Estimate } \\
\text { (O) }\end{array}$ & $\begin{array}{c}\text { Sample } \\
\text { Mean } \\
(\mathrm{M})\end{array}$ & $\begin{array}{c}\text { Standard } \\
\text { Deviation } \\
\text { (STD) }\end{array}$ & $\begin{array}{c}\text { t Statistcs } \\
(\mathrm{IO} / \mathrm{STDEVI})\end{array}$ & $\begin{array}{c}\mathrm{p} \\
\text { Values }\end{array}$ \\
\hline $\begin{array}{l}\text { Faktor eksternal } \rightarrow \\
\text { faktor internal }\end{array}$ & 0,583 & 0,604 & 0,097 & 5,980 & 0,000 \\
\hline $\begin{array}{l}\text { Faktor eksternal } \rightarrow \\
\text { Kesejahteraan petani }\end{array}$ & 0,659 & 0,665 & 0,116 & 5,671 & 0,000 \\
\hline $\begin{array}{l}\text { Faktor internal } \rightarrow \\
\text { Kesejahteraan petani }\end{array}$ & 0,024 & 0,022 & 0,135 & 0,178 & 0,859 \\
\hline
\end{tabular}

Pengujian hipotesis berdasarkan hasil perhitungan yang disajikan di Tabel 5 menunjukkan bahwa faktor eksternal berpengaruh sangat signifikan terhadap faktor internal dengan koefisien jalur sebesar 0,583 dan $p$ value $<0,01$. Faktor eksternal juga berpengaruh sangat signifikan terhadap kesejahteraan petani dengan koefisien jalur 0,659 dan $p$ value $<0,01$. Sementara faktor internal tidak berpengaruh signifikan terhadap kesejahteraan petani dengan koefisien jalur 0,024 dan $p$ value $>0,01$. Belum ada hasil penelitian sebelumnya yang membahasa tentang hal ini, namun Prasetya et al. (2021) menemukan bahwa faktor internal yang berpengaruh terhadap tingkat resistensi petani adalah keterampilan dan norma subjektif, sementara faktor internal yang dimasukkan dalam analisis ini adalah jumlah anggota keluarga dan pengalaman berusahatani.

Temuan ini menunjukkan bahwa banyaknya anggota keluarga petani dan pengalaman berusahatani tidak menentukan tinggi rendahnya kesejahteraan petani yang diukur dengan pendapatan dan kondisi rumah tinggal petani. Faktanya, penerimaan petani rendah karena petani menjual biji mete dalam bentuk gelondongan yang dihargai rendah oleh pedagang. Nilai jual yang rendah tidak memungkinkan petani untuk investasi kembali di usahatani jambu mete karena pendapatannya juga digunakan untuk keperluan rumah tangga. Faktor eksternal dengan indikatornya yaitu peran penyuluh pertanian, akses ke modal, jumlah modal yang dipinjam, dan harga kacang mete sangat menentukan kesejahteraan petani. Pengaruh sangat signifikan baik secara langsung maupun tidak langsung menunjukkan pentingnya variabel ini bagi kesejahteraan petani. Fakta ini juga mengindikasikan bahwa petani jambu mete di Desa 
Mata Kapore memerlukan campur tangan pihak lain untuk dapat meningkatkan kesejahteraan dirinya sendiri. Para petani ini tidak bisa melakukannya sendiri, terkait dengan kondisi internal mereka terutama karena pendidikan relatif rendah sehingga akses modalnya rendah, tidak memiliki jaminan untuk meminjam modal karena lahan yang dikuasainya relatif sempit. Hasil ini sejalan dengan penelitian yang telah dilakukan oleh Iqbal \& Dalimi (2019) bahwa petani juga mengalami masalah kelembagaan. Namun berbeda dengan hasil penelitian Yusria (2010) dan Fyka et al. (2019) bahwa rumah tangga petani jambu mete di Kabupaten Buton Sulawesi Selatan tergolong sejahtera.

\section{Kesimpulan}

Kesejahteraan petani jambu di Desa Mata Kapore termasuk ke dalam kategori cukup dilihat dari tingkat pendapatan, dan kondisi tempat tinggal. Faktor internal tidak berpengaruh signifikan terhadap kesejahteraan petani. Faktor eksternal berpengaruh sangat signifikan terhadap kesejahteraan petani, baik secara langsung maupun secara tidak langsung melalui faktor internal. Indikator dari faktor eksternal meliputi peran penyuluh, akses pada modal, jumlah modal pinjaman, dan harga komoditi kacang mete. Indikator dari faktor internal adalah banyaknya anggota keluarga dan pengalaman berusahatani.

Dalam rangka meningkatkan kesejahteraan petani, perlu dukungan berbagai pihak (pemerintah melalui penyuluh pertanian, lembaga keuangan, pihak swasta) untuk memberikan akses pada modal dan jaminan harga bagi petani jambu mete. Penelitian selanjutnya dapat menggunakan indikator bagi faktor internal dan eksternal yang lebih banyak dan lebih terukur.

\section{Daftar Pustaka}

Fauziyah, E., Aniyatussholihah, \& Hidayati, D. R. (2017). Strategy of Export Competitiveness Enhancement on Cashew Nut Commodity. JEJAK Journal of Economics and Policy, 10(2), 302-316. https://doi.org/http://dx.doi.org/10.15294/ jejak.v10i2.11295.

Guledgudda, S. S., Patil, B. L., \& Rajur, B. C. (2014). Export performance of Indian cashewnut - An analysis. Economic Affairs, 59(4), 669-674. https:/ / doi.org/10.5958/ 0976-4666.2014.00041.2

Hakim, N. (2018). Jurnal mega aktiva. Jurnal Mega Aktiva, 7 (April), 1-10.

Hartati, G. A. R., Budhi, M. K. S., \& Yuliarmi, N. N. (2017). Analisis faktor-faktor yang mempengaruhi kesejahteraan petani di Kota Denpasar. E-Jurnal Ekonomi Dan Bisnis, 6(4), 1513-1546.

Indrawanto, C. (2004). Peningkatan Daya Saing Industri Mente Indonesia Melalui Pembentukan Klaster Industri Mente. Perspektif, 3(1), 15-23.

Kurniawan, B. P. Y. (2016). Strategi dan Prospek Pengembangan Jambu Mete (Anacardium occidentale. L) Kabupaten Jember. Jurnal Manajemen Teori dan Terapan, 9(3), 242-258.

Muhammad Hardika Prasetya, M. H., Zebua, D.D.N., \& Yuliawati. 2021. Faktor Internal 
dan Eksternal Yang Mempengaruhi Tingkat Resistensi Petani Terhadap Usahatani Padi Organik. Jurnal Sosial Ekonomi Pertanian, 17 (1), 39-51.

Pudjiastuti, A. Q. (2014). Perubahan Neraca Perdagangan Indonesia Sebagai Akibat Penghapusan Tarif Impor Gula. Agriekonomika, 3(2), 106-116.

Pudjiastuti, A. Q., Anindita, R., Hanani, N., \& Kaluge, D. (2013). Effects of Sugar Price Increase in Indonesia. Oeconomica, 58(1), 28-39. https://doi.org/http:// studiaoeconomica.ubbcluj.ro/volumes.html

Pudjiastuti, A. Q., \& Kembauw, E. (2018). Sugar Price Policy and Indonesia's Trade Balance. Journal of Advanced Research in Law and Economics, 8(8). https:/ / doi.org/10.14505/jarle.v8.8(30).26

Zahir, N., \& Sanawiri, B. (2018). Analisis Daya Saing Kacang Mete Indonesia di Pasar Internasional ( Studi tentang Kacang Mete Indonesia Tahun 2011-2015 ). Jurnal Administrasi Bisnis (JAB), 54(1), 66-73.

Yusria, W. O. (2010). Keadaan Ekonomi Rumahtangga Petani Jambu Mete Di Kabupaten Buton Sulawesi Tenggara. Jurnal AGRISEP, 9(2), 109-119. https:/ / doi.org/10.31186/jagrisep.9.2.109-119 